Seloka: Jurnal Pendidikan Bahasa dan Sastra Indonesia
UNNES $(3020): 239-246$
$h t t p s: / / j o u r n a l . u n n e s . a c . i d / s j u /$ index.php/seloka

\title{
Characteristics of Writing Explanation Text Enrichment Book Containing 21st Century Competence for Senior High School Students
}

\author{
Nurul Badriyah ${ }^{1 凶}$, Ida Zulaeha ${ }^{2}$, Wagiran Wagiran ${ }^{2}$ \\ ${ }^{1}$ SMA Negeri 1 Randudongkal, Jawa Tengah, Indonesia \\ ${ }^{2}$ Universitas Negeri Semarang, Indonesia
}

\begin{tabular}{l} 
Article Info \\
\hline History Articles \\
Received: \\
August 2020 \\
Accepted: \\
Oktober 2020 \\
Published: \\
Desember 2020 \\
\hline Keywords: \\
Enrichment Book, \\
Explanatory Text, 21st \\
Century Competence
\end{tabular}

\begin{abstract}
The formation of student personalities that can be developed with writing explanatory texts enrichment book containing 21st century competencies includes aspects of knowledge, skills, and personality that are integrated with 21st century competencies that students must master. This study aims to analyze the need for enrichment book development in writing explanatory text with 21st century competencies and the characteristics of enrichment book development for writing explanatory text with 21st century competence. The research method uses the Research and Development and uses six steps out of ten steps in the R\&D method. The results obtained from this study were an analysis of the needs of students and teachers which were grouped based on question aspects, namely (1) material and content needs, (2) 21st century competency content needs, (3) presentation needs, (4) language needs. and (5) legibility and graphics needs. This needs analysis is to determine the tendency of the needs of students and teachers to the form of the enrichment book being developed. Then, the characteristics of the enrichment book are writing explanatory texts containing 21st century competencies according to the perceptions of students and teachers in accordance with the principles of content feasibility, presentation feasibility, linguistic feasibility, and graphic feasibility. In addition, teachers and students are very in accordance with the form of the book that is being made easy to carry. Therefore, the development of an enrichment book to write explanatory texts containing 21st century competencies is in accordance with the wishes of teachers and students in using a learning resource.
\end{abstract}

\footnotetext{
$凶$ Correspondence address:

Leyangan, Kecamatan Ungaran Timur, Kabupaten Semarang,

Provinsi Jawa Tengah, Indonesia

p-ISSN 2301-6744

E-mail: norinshah16@gmail.com

e-ISSN 2502-4493
} 


\section{INTRODUCTION}

Enrichment books have an important role in the learning process. This is in accordance with Permendiknas article 6 (2) year No. 2 of 2008 which states that "apart from textbooks, educators can use educators' manuals, enrichment books, and reference books in the learning process". Based on the results of observations at school, educators have used enrichment books to write explanatory texts for students, but these books have not integrated the content of $21 \mathrm{st}$ century competencies. After reading and studying the enrichment books available, they only provide material with assignments that only develop writing skills but have not applied 21st Century skills to learning.

Enrichment books are a support or companion in learning which in nature increase knowledge, improve skills and shape the personality of the participants (Afandi and Zulaeha 2017; Septianto and Subyantoro 2016 :). The personality formation of students that can be developed with this enrichment book includes aspects of knowledge, skills, and personality that are integrated with 21st Century competencies that students must master.

Abidin (2012) from various studies stated that the ability to write still leaves a serious problem for basic education to tertiary institutions. Writing competence is a form of productive language proficiency which has great benefits for students. Writing also increases the intelligence activities of students, develops initiative and creativity, fosters courage and encourages willpower, as well as the ability to collect information Suparno (2007). This condition can be used optimally for training and developing the mindset and reasoning of students in expressing opinions, because writing will hone the language skills used to communicate indirectly in order to express ideas and convey them through written language to others so that they are easily understood ( Nurudin 2010).
Writing also enhances creativity to create something that is creative and contains power. Creativity is a way of appreciating ourselves to a problem in various ways that come spontaneously which is the result of our thinking (Zulaeha, 2008). When writing, a person expresses ideas, thoughts and feelings. In line with this, students can also choose the right words that can represent ideas, thoughts, and feelings.

Regarding writing skills, one of the writing skills that students must master is learning to write explanatory text. Anderson \& Anderson (2003) states that the meaning of explanation is an expression both orally and in writing about why or how an event occurs. From several existing enrichment books, enrichment books, seen from the content and material developed in the enrichment book, it can be concluded that not all books used in lessons contain enrichment that focuses on students. Even though the 2013 curriculum learning should always focus on students from existing information in accordance with learning. Therefore, we need student-centered enrichment books that can improve explanatory text writing skills by thinking critically, creatively, collaboratively, and communicatively.

The implementation of 21st Century competence in an enrichment book. Each lesson is accompanied by a content of 21 st century competencies found in examples of explanatory text along with student activities in understanding the contents of the text through the 21st Century skills being learned. The learning objective is to determine the extent to which the 21st century competences are implemented for students who are developed in the enrichment book.

21st Century competencies require metacognitive and self-reflective abilities. Jamaludin (2017) in his research states that the development of an appropriate selfconcept opment in the 21st century is important for greater expertise in a person on 
metacognitive and self-reflective abilities. Med (1934) in Jamaludin (2017) explains the concept of self as a social construction that involves a level of awareness being considered another person in social terms. Students and teachers are able to integrate the social components that exist in the school environment and the environment where they live at the time of learning.

In the 21 st century, technological advances have also entered various aspects of life. Teachers and students, lecturers and students are required to have the ability to learn to teach in the 21 st century. The forms of utilizing information technology in the 21 st century are contributing to preparing 21st Century MOOCs learning (Goto, Batchelor, and Lautenbach, 2015), videobased learning (Nino and Evans 2015), the use of e-learning using both LMS (learning management system) or other learning applications (Tamimudin H, 2105) and users of mobile learning as learning media (Lai and Hwang, 2014). 21st century national education aims to realize the ideals of the nation, namely a prosperous and happy Indonesian society, with an honorable and equal position with other nations in the global world, through the formation of a society consisting of quality human resources, namely independent, willing and able to realize the ideals of their nation (BSNP, 2010).

Relevant to these descriptions, it can be concluded that research on the development of enrichment books writing explanatory texts with 21st century competencies for high school students is deemed important. The book aims to improve explanatory text writing skills with 21st century competences in students. The development of books in this study is expected to be used as a facility for students and educators, in developing explanatory text writing skills by implementing creative and innovative skills, communicative, collaborative, and critical thinking. Prayogi and Aesthetics (2019) in the research stated that supporting success in the digital era requires a skill base in the digital era, including critical thinking skills, problem solving, communication, and collaboration. Therefore, the topic of developing enrichment books is very interesting to be examined from the needs and characteristics of enrichment books for students and teachers.

\section{METHOD}

This study uses the research and development (R\&D) method. Borg and Gall (in Sugiyono, 2010) research and development is a research method used to produce certain products and test the effectiveness of the product, there are ten steps for implementing research and development. This research reduces to the sixth implementation step, namely design revision, the six steps include (1) information gathering, (2) prototype design, (3) design validation, (4) design revision, (5) prototype testing, (6) ) revision of the prototype.

The tendency of the needs of students and teachers to determine the form of enrichment book development. There are various aspects of needs for students and teachers. The questions posed to students and teachers determine the content in creating enrichment books. Several considerations based on the results of the distribution of the trend questionnaire for the needs of students and teachers resulted in the principle of developing enrichment books.

The variables of this research can be grouped into four, namely (1) the profile of the enrichment book to write explanatory text containing 21st century competencies that are needed according to the perceptions of teachers and students, (2) the profile of the writing explanatory text enrichment book with 21 st century competence according to the assessment. validators, and (3) the profile of the characteristics of the writing explanatory text enrichment book containing 21 st century competences, (4) the acceptance 
profile of the writing explanatory text enrichment book containing 21st century competences.

The data of this study are the data on the needs of teachers and students for enrichment books in writing explanatory texts containing 21 st century competencies and the acceptance of enrichment books for writing explanatory texts containing 21st century competencies. The data on these needs are in the form of scores and percentages of the tendency for enrichment books to write explanatory texts with 21 st century competencies. Then the perceptions of teachers and students obtained from the analysis of the characteristics of the writing explanatory text enrichment book containing 21st century competences. In addition, another score is obtained from expert judgment in the form of enrichment book profiles writing explanatory text with $21 \mathrm{st}$ century competences. The scores obtained from the skills of students in understanding the contents of the writing explanatory texts enrichment book containing 21st century competencies with the acceptance of the enrichment book.

In this study, four categories of research data sources were used. First, the data source of the needs analysis for the writing explanatory text enrichment book containing 21st century competencies according to the perceptions of high school students and according to teachers in three different schools, namely SMA Negeri 1 Randudongkal, MA Salafiyah Safiiyah Proto, Kedungwuni, Pekalongan, and MA Safiiyah Symbol. Second, the description of the characteristics of the writing explanatory texts enrichment book containing 21st century competencies according to the perceptions of teachers and students. Third, the expert validator who will assess the profile of the writing explanatory text enrichment book with 21st century competencies for high school students, namely Dr. Mukh Doyin, M.Si and Dr. Imam Baehaqie, M.Hum. Fourth, the acceptability of the enrichment book to write explanatory texts containing 21st century competencies according to the perceptions of teachers and students.

\section{RESULT AND DISCUSSION}

The needs of students and teachers for enrichment books to write explanatory texts with 21st century competencies include (1) the needs of students for the content of enrichment book materials to write explanatory texts with 21st century competencies, (2) the needs of students for presenting enrichment books in writing explanatory text containing 21st century competence, (3) the need of students for language and legibility of books of knowledge, writing explanatory text with 21st century competencies, (4) the needs of students for the draft of the book pengayana write explanatory text with 21st Century competencies, and (5) ) The hope of enrichment book students in writing explanatory texts with 21st Century competences.

In the material or content aspect, a questionnaire is presented which contains several questions regarding the responses of students and teachers to the explanatory text material in the pengayan book. In addition to these questions, the questionnaire also contains questions to distinguish explanatory texts from other texts. Based on the data obtained from the needs analysis interview, it was explained that 18 of the 30 students had studied the explanatory text material. Then, 18 out of 30 students were also able to distinguish explanatory text from other texts. Learning resources used in learning are textbooks, internet, and newspapers. Learning conditions related to 21 st Century competency content, 27 out of 30 students agreed to insert 21st Century competencies to increase student creativity and innovation in writing explanatory text. From the questionnaire analysis of teacher needs, it 
was also obtained that the results of the four teachers hoped that the enrichment book developed contained explanatory text material with 21 st Century competencies along with examples of explanatory text that explored the creativity of students in writing explanatory texts along with their reviews.

The next aspect is the aspect of presenting the book material. Based on the data obtained from the interview the need for presenting enrichment book material, 15 students needed instructions for using enrichment books and 22 students thought there was a need for a summary of the material in each chapter. The structure of the presentation of the explanatory text content needs to be presented in the enrichment book being developed. Based on the results of the analysis of teacher needs, it is known that the icons of 21st Century competency content can foster student creativity and innovation.

Based on the results of the analysis of the needs for aspects of language and book illustrations. The four teachers agreed that there was the use of a variety of communicative language but did not leave the standard of the language, it was aimed at making students accustomed to using Indonesian in accordance with the Enhanced Spelling Guidelines. In addition, the use of language that is light, straightforward, and communicative makes students better understand the material presented. Then, an attractive illustration can give students interest in increasing reading interest. The existence of illustrations according to Sitepu (2012) can help students understand concepts that are difficult to explain in words. The form of illustration used can be in the form of color images that support students' understanding.

The book graphic aspect provides several indicators to determine the needs of students and teachers. These indicators relate to the cover color design, cover design, and book size. Based on the interviews conducted to determine the needs of the graphic aspects, data obtained from 13 students wanted a bright color combination with black. Book size does not affect students' reading interest. Based on the results of the teacher needs analysis, it is hoped that the books to be developed are easy to carry and not too big. The expected thickness of the book with the appropriate number of pages will minimize the reader's boredom. This is based on the results of the analysis of the needs questionnaire and interviews with the teacher.

Based on the needs analysis, it is hoped that the book can be made as attractive as possible in simple language and is easily understood by students and other readers. The book is not too thick so it does not burden students to carry the book. Book content related to material and examples of explanatory text can encourage students to read and implement the content of 21st Century competencies that exist in everyday life. The enrichment book for writing explanatory texts containing 21st Century competencies is expected to be able to make students more creative and innovative who can communicate and collaborate their knowledge with knowledge of the surrounding environment experienced in everyday life. The hope of the teacher that the enrichment book that will be produced is also expected to provide prior understanding of the differences in explanatory text and exposition text. Books must be made as attractive as possible in language that is easy for students to understand. So that it can attract students to read it.

Based on the results of the analysis of structured interviews with students and teachers, the characteristics of the need for enrichment books are then formulated into the principles of developing enrichment books to write explanatory texts containing 21st Century competencies. , namely: (1) material aspects or book content, (2) presentation aspects, (3) language aspects, (4) graphic aspects.

Characteristics of enrichment books writing explanatory texts containing $21 \mathrm{st}$ 
Century competencies are developed specifically based on standard quality criteria for enrichment books based on needs including content feasibility, resulting in enrichment book principles consisting of the principle of completeness, the principle of conformity, the principle of 21st century competence, the principle of relevance, and the reality principle. The feasibility of the material was produced from the principle of completing the material for writing explanatory texts containing 21st Century competencies and the principle of reality. Feasibility of presentation includes the presentation of material to write explanatory text, the principle of presenting complementary components of material such as material summaries and the strength of students' understanding. Language feasibility includes the principle of how to explain the material, the principle of using types of sentences, and the principle of using various languages. Furthermore, the feasibility of graphics includes the principles of book shape, the principles of type and size of letters, and the principles of using attractive, creative, and innovative book covers.

The enrichment book containing 21st Century competencies covering 4 categories is described as follows: (a) ways of thinking creativity and innovation, (b) ways to work, communicate and cooperate, (c) tools for work, general knowledge and information technology skills and communication, (d) ways to live, careers, be personally and socially responsible, including awareness of culture and competence (Brinkley et al, 2018). Kim Sharon (2019) in the study concluded that To create 21st Century learners, we must focus on 21st Century teacher skills and rethink how we can evaluate and train teachers.

The enrichment book that implements 21st Century competencies also has the characteristics of developing professional active learning competencies for each student by being able to contribute quickly and positively to the organization's learning abilities and innovative capacities.

The characteristics of the explanatory text enrichment book material with 21st Century competencies are also arranged based on completeness, suitability and relevance. The material needed by students and teachers in mastering the basic competences of writing explanatory text, namely (1) understanding of explanatory text, (2) characteristics of explanatory text, (3) purpose of explanatory text, (4) structure of explanatory text, (5) rules of language explanatory text, and (6) examples of explanatory text with 21st Century competences.

The emphasis of the material and exercises are presented on the material of writing explanatory text with the aim of strengthening the skills of students in writing explanatory text. The principle of conformity is applied by providing material that is in accordance with the level of understanding and experience of students at the high school level or equivalent. This aspect of the presentation of the material is also in accordance with the characteristics of the explanatory text which constructs between reality and development in writing explanatory text. This is in line with Wulansari and Zulaeha's (2018) research which states that explanatory text learning is developed with a social system constructing the knowledge of teachers and students.

21st century competencies are competencies that have critical thinking skills, creative and innovative, collaborative, communicative, and analytical. This concept makes students learn to collaborate the knowledge they have from learning in school with general knowledge gained from personal experience. This is in line with the opinion in Longmore's (2017) study that students and learning expand their selfunderstanding of their knowledge, skills and abilities to create, analyze, and transform information into a transfer of student insights. 
Characteristics in the presentation aspect. The principle of coarseness is applied by presenting the material in the enrichment book in a coherent and gradual manner. Therefore, the book developed consists of three chapters, namely (1) chapter 1 recognizing the content of 21st Century competencies (containing the essence of 21st Century competencies, 21st Century competency values, and existing skills in 21 st Century competencies. 21), chapter 2 recognizes explanatory text with 21 st century competencies (contains objectives, structures, and language rules of explanatory text with 21st century competencies), in this it also contains the concept of writing, steps to write explanatory text, and development methods. explanatory text contains 21st Century competences, and chapter 3 contains explanatory text examples containing 21st Century competencies, these examples are also complemented by existing skills in 21st Century competencies.

The principle of newness is manifested by designing the presentation of material that is different from other books. In the enrichment book that was developed in addition to the presentation of the material, a review of 21 st century competence was also added.

The principle of novelty is realized by designing the presentation of the material that is different from other books. In the enrichment book that was developed in addition to the presentation of the material, it was also added to the review of $21 \mathrm{st}$ Century competency skills. The principle of conformity is manifested by the use of diction, sentences and paragraphs that are in accordance with the level of intelligence of students. The use of diction used in the enrichment book is adjusted to the diction used in everyday life.

The last characteristic is in the graphic aspect. Graphic aspects include suitability, attractiveness, and consistency. The principle of conformity is manifested by designing enrichment books in accordance with the characteristics of students and teachers in the graphic aspect. This is done so that the needs of students and teachers are met so that it will attract readers to study the enrichment book being developed. This consistency principle is manifested in the use of fonts and spacing according to the characteristics of needs, namely using Times New Roman and Bahnscrift fonts with a size of 12 for material and examples, while for 21st century proficiency reviews also use a size 12 . The distance between letters uses 1.5 spaces for writing material and examples of text presented. This is so that the distance between words is not too tight so that it is easy to read.

\section{CONCLUSION}

One of the characteristics of enrichment books in the 21st century is implementing $4 \mathrm{~K}$, namely critical thinking and problem solving, communicative, collaborative, creative and innovative. The enrichment book containing 21st Century competencies covering 4 categories is described as follows: (a) creative thinking and innovation, (b) ways to work, communicate and collaborate, (c) ways to socialize about culture and competence (Brinkley et al, 2018). To create 21st century learners, we must focus on 21st Century teacher skills and rethink how we can evaluate and train teachers.

Enrichment books of write explanatory texts containing 21st Century competencies based on the tendencies of teachers and students. Teachers and students expect the development of teaching materials to be complete, detailed, interesting, and able to guide students to be more creative and innovative in writing explanatory text. Furthermore, enrichment books writing explanatory texts containing 21st Century competencies can be used as supporting books and companion books in learning. 


\section{REFERENCES}

Abidin, Yunus. (2012). Pembelajaran Bahasa Berbasis Pendidikan Karakter. Bandung: Refika Aditama.

Afandi, Muhammad Idris dan Ida Zulaeha. (2017). "Keefektifan Buku Pengayaan Menulis Teks Hasil Observasi Bermuatan Multikultural Berbasis Proyek Baca Tulis untuk Peserta Didik SMP”. Jurnal Seloka Pendidikan Bahasa dan sastra Indonesia UNNES. 6(2) 1-13.

Anderson, J.A. (2003). Critical Thinking Across the Disciplines. Makalah pada Faculty Development Seminar in New York City College of Technology, New York.

Jamaludin. (2017). "Problem-Solving for STEM Learning: Navigating Games As Narrativized Problem Spaces For 21st Century Competencies". Technology Enhanced Learning. 12(1) 1-14.

Kim, Sharon.. (2019). "Improving 21stcentury teaching skills: The key to effective 21stcentury learners". SAGE Journal. 19(1): 1-19.

Longmore. (2017). "Closing the 21stCentury Knowledge Gap: Reconceptualizing Teaching and Learning to Transform Business Education". SAGE Journal.20(20) 123

Nurudin. (2010). Dasar-Dasar Penulisan. Malang: UMM Press.

Pusat Perbukuan Depdiknas. (2008). Pedoman Penulisan Buku Nonteks (Buku Pengayaan, Referensi, dan Panduan Pendidik). Jakarta: Puskurbuk.

Prayogi, Rayinda D, Rio Estetika. (2019). "Kecakapan Abad 21: Kompetensi Digital Pendidik Masa Depan". Jurnal Manajemen Pendidikan. 14(2): 144-151
Sitepu. (2012). Penulisan Buku Teks Pelajaran. Bandung: PT Remaja Rosdakarya.

Sugiyono. (2009). Metodologi Penelitian Kualitatif, Kuantitatif, dan R\&D. Bandung: Alfabeta.

Wulandari, Desi Eka dan Ida Zulaeha. (2018). Keefektifan Pembelajaran Menyusun Teks Eksplanasi dengan Model Investigasi Kelompok dan Problem Based Learning pada Peserta Didik Kelas VII SMP. Seloka Jurnal Bahasa dan Sastra Bahasa Indonesia UNNES. 7(2) 22-28

Zulaeha, Ida. (2008). Kebutuhan Pendidik, Peserta didik, Materi Ajar, dan Strategi dalam Pengembangan Pembelajaran Menulis Kreatif Konteks Multikultur. Journal of Educational Research Lembaran Ilmu Kependidikan (LIK). 37(2): 126-133.

Zulaeha, Ida, (2016). Teori, Model, dan Implementasi Pembelajaran Menulis Kreatif. Semarang: Unnes Pres. 
Nurul Badriyah et al./Seloka: Jurnal Pendidikan Bahasa dan Sastra Indonesia 9 (3) (2020) :239-246 